logos_i_ethos_2017_(45)_numer specjalny, s. 135-147

DOI: http://dx.doi.org/10.15633/lie.2342

\author{
Joanna Mysona Byrska \\ Uniwersytet Papieski Jana Pawła II w Krakowie
}

\title{
Konsumpcjonizm jako błąd mentalny
}

Społeczeństwo konsumpcyjne to jedna z odmian społeczeństwa ponowoczesnego, w którym wiele wartości zaczyna być rozumianych inaczej niż dotychczas. Dość często w przestrzeni publicznej można usłyszeć głosy nawołujące do ograniczania konsumpcji, ponieważ jest ona dla człowieka czymś niekorzystnym,

Joanna Mysona Byrska, prof. UPJPII, dr hab., kierownik Katedry Filozofii Społecznej i Polityki, Wydział Filozoficzny Uniwersytetu Papieskiego Jana Pawła II w Krakowie. Zainteresowania: filozofia społeczna, filozofia polityki, etyka stosowana. Publikacje: Etyczne aspekty demokracji, Kraków 2012, Wykłady z etyki ogólnej, Kraków 2015, O polityce polityczności i antypolityce, Kraków 2016.

a nawet może stać się groźna. Każdy z nas jest konsumentem - nie da się od tego uciec, ponieważ człowiek musi konsumować, żeby przeżyć. Czy można być konsumentem, nie popadając w konsumpcjonizm, czyli takim, który w praktyce stosuje słynną arystotelesowską zasadę złotego środka i umiaru - cnoty kardynalnej? Czy cnota roztropności (fronesis), również uznawana przez Arystotelesa za jedną z czterech cnót kardynalnych, jest w stanie uchronić człowieka przed popadnięciem w konsumpcjonizm? Świat konsumpcji to świat nadmiaru, wydaje się, że obie wymienione cnoty kardynalne stanowią przeciwieństwo tego, czego oczekuje świat konsumpcji od konsumenta.

\section{Konsumpcja do przesady}

Druga połowa XX wieku przyniosła ze sobą wiele zmian społecznych. Jest to okres, w którym społeczeństwo produkcyjne przekształca się w społeczeństwo konsumpcyjne. Społeczeństwo produkcyjne to społeczeństwo, w którym produkcja zaspokaja już istniejące potrzeby 
człowieka: nabywcy czekają na dobra, które są zgodnie z ich potrzebami produkowane. Popyt dominuje nad podażą lub jest jej równy. Czasami oznacza to, że poszukiwanych dóbr jest zbyt mało lub dokładnie tyle, ile potrzeba w danej chwili. Nie pojawia się jednak zjawisko wszechobecnego nadmiaru i przesytu.

Społeczeństwo konsumpcyjne to społeczeństwo, w którym wiele potrzeb człowieka - trzeba zaznaczyć, że nie wszystkie - jest generowanych sztucznie, ponieważ dobra już zostały wyprodukowane i szukają swoich nabywców, zalegając w magazynach i na półkach sklepowych. Potencjalnego konsumenta trzeba zachęcić do nabycia i używania lub zmiany już posiadanych przedmiotów na nowe. Cechą charakterystyczną społeczeństwa konsumpcyjnego jest zjawisko nadprodukcji i nadmiaru. Produkty czekają na klienta, czekają aż zostaną skonsumowane. Zadaniem konsumenta jest ich kupowanie, użytkowanie i zużywanie.

Aby dobra już wyprodukowane mogły znaleźć swoich nabywców, człowieka należy nauczyć, że posiada potrzeby, z których posiadania do tej pory nie zdawał sobie sprawy. Jest to zadanie reklam oraz tzw. celebrytów, którzy pokazują zwykłym konsumentom, co i jak należy konsumować ${ }^{1}$. Konsumenta należy również przekonać, że nowe jest lepsze od starego - stare dobra w świecie konsumpcji wymienia się na nowe. Truizmem wydaje się stwierdzenie, że nowe jest lepsze od starego - w świecie konsumpcji nie jest to truizm, ale jedna $\mathrm{z}$ ważniejszych zasad, zgodnie z którymi ten świat funkcjonuje ${ }^{2}$. Nadmiar to jedna z cech charakterystycznych świata konsumpcji, dlatego konsumpcja powinna stale rosnąć.

W świecie i społeczeństwie konsumpcyjnym konsumentem jest każdy niezależnie od wieku - dzieci (nawet bardzo małe) stanowią duży rynek zbytu, należy im jednie uświadomić, że posiadają specyficzne potrzeby,

1 Por. J. Baudrillard, Społeczeństwo konsumpcyjne. Jego mity i struktury, przeł. S. Królak, Warszawa 2006, s. 41. Por. J. Mysona Byrska, The Promotion of the Infantilism Ethos in Consumer Society, "Ethics \& Bioethics (in Central Europe)" 5 (2015) issue 1-2, s. 59-66.

2 Nowość $\mathrm{w}$ świecie konsumpcji staje się wyznacznikiem poziomu życia, jedną z ważnych tzw. „nowych wartości” - tego, co świadczy w świecie konsumpcji o poziomie życia i znaczeniu jednostki - konsumenta. Odnośnie do nowości zob. J. Baudrillard, Społeczeństwo konsumpcyjne..., dz. cyt., s. 58. 
które mogą zaspokoić, dostając odpowiednie, czyli aktualnie reklamowane produkty ${ }^{3}$. Co więcej, bez tych produktów (które obiektywnie wcale nie muszą być potrzebne) człowiek w świecie konsumpcji nie będzie odpowiednio wyposażony i będzie marginalizowany - o człowieku świadczą przedmioty, jakimi się otacza i to one nadają mu wartość. Dostrzegał to bardzo wyraźnie Jean Baudrillard, krytycznie stwierdzając, że o wartości człowieka w świecie konsumpcji świadczy stan jego posiadania i zasobność portfela, a nie umiejętność myślenia i tworzenia ${ }^{4}$.

Każdy człowiek jest konsumentem - każdy konsumuje, czyli przetwarza produkty i dobra. Martin Lindstrom pisze: „Spójrzmy prawdzie w oczy - wszyscy jesteśmy konsumentami. Niezależnie od tego, co kupujemy - telefon komórkowy, szwajcarski krem przeciwzmarszczkowy czy coca-colę - zakupy stanowią ogromną część naszego codziennego życia"5. Nie można nie konsumować w ogóle. Można jednak, jak się wydaje, spróbować uciec ze świata konsumpcji, w którym człowiek jest podporządkowany przedmiotom i staje się stopniowo ich sługą, gdyż stoi to w rażącej sprzeczności do słynnego imperatywu kategorycznego Kanta, wedle którego to człowiek ma być celem - nigdy tylko środkiem ${ }^{6}$. Świat konsumpcji podporządkowuje człowieka konsumpcji. Oporni są marginalizowani, a nawet wypychani poza ramy bogatego świata konsumpcji i stanowią smutną grupę tzw. „strat ubocznych” - tak nazywa ich Zygmunt Bauman, pokazując, że bogaty i bezpieczny świat konsumpcji jest dla wybranych - tych, których na to stać ${ }^{7}$. Pytanie, jakie drogi ucieczki ze świata konsumpcji są możliwe.

3 Por. J. Bakan, Dzieciństwo w stanie oblężenia. Łatwy cel wielkiego biznesu, Warszawa 2013.

${ }_{4}$ Zob. J. Baudrillard, Społeczeństwo konsumpcyjne..., dz. cyt., passim.

${ }_{5}$ M. Lindstrom, Zakupologia: prawda i kłamstwa o tym, dlaczego kupujemy, przeł. M. Zielińska, Kraków 2009, s. 5.

6 „Postępuj tak, byś człowieczeństwa tak w twej osobie, jako też w osobie każdego innego używał zawsze zarazem jako celu, nigdy tylko jako środka” (I. Kant, Uzasadnienie metafizyki moralności, przeł. M. Wartenberg, Warszawa 1984, s. 62).

7 Zob. Z. Bauman, Straty uboczne: nierówności społeczne w epoce globalizacji, przeł. J. Hunia, Kraków 2012, s. 11, por. J. Mysona Byrska, Zbywatele, prekariusze i praca w świecie konsumpcji, „Filo-Sofija" 15 (2015) nr 29 (2/II): Z problemów wspótczesnej filozofii, s. 206. 
W tym miejscu uwidacznia się też zasadniczy problem - kiedy człowiek, który ze względu na swoją konstrukcję musi konsumować, staje się konsumentem - modelowym przedstawicielem społeczeństwa i świata konsumpcji? Kiedy zatraca się w konsumpcji, a konsumowanie staje się celem i sensem jego życia?

Aby odpowiedzieć na to zasadnicze pytanie o granicę pomiędzy zwyczajną konsumpcją a konsumeryzmem, należy po krótce przedstawić, co stanowi istotę konsumpcjonizm i jakie są jego charakterystyczne przejawy.

\section{Kult zakupów i świątynia konsumpcji}

Georg Ritzer - amerykański badacz współczesnego społeczeństwa nazwał współczesne wielkie galerie handlowe, takie jak np. Galeria Krakowska, świątyniami konsumpcji. Współcześnie przyciągają one ludzi nierzadko mocniej niż świątynie. Zapewniają zaspokojenie społecznych potrzeb człowieka, takich jak bycie razem, wspólne przeżywanie czasu, celebrowanie czegoś ważnego, czyli świętowanie - stwierdza Ritzer ${ }^{8}$. Galerie handlowe są tak konstruowane, że zaspokajają wymienione potrzeby. Te współczesne świątynie konsumpcji są przepełnione dobrami, bardzo kolorowe, stale kuszą nowymi promocjami i nowymi produktami. Są miejscem „kultu zakupów”, który jest rodzajem „nowej religii”. Kupowanie, a właściwie kupowactwo, zaspokaja pustkę egzystencjalną konsumenta. Zaspokojenie jest tylko chwilowe, ponieważ kupiony przedmiot tylko przez chwilę jest nowy, łady i daje poczucie spełnienia, ale dzięki temu konsument może ponownie wyruszyć na zakupy - na pielgrzymkę do świątyni konsumpcji ${ }^{9}$. Zakupy i galerie handlowe - świątynie konsumpcji są dlatego tak ważne, bo pomagają konsumentowi przynajmniej na chwilę uporządkować świat, w którym żyje, a który jest pełen zmian i braku stabilności. Kupując przedmiot, konsument przez chwilę ma

8 G. Ritzer, Magiczny świat konsumpcji, przeł. H. Jankowska, Warszawa 2009, s. 24.

9 Por. K. Walotek-Ściańska, Homo Consumens, http://www.sbc.org.pl/Content/134276/Walotek\%C5\%9Acia\%C5\%84ska.pdf (25.04.2017). 
poczucie panowania nad rzeczywistością - z tego powodu zakupy stają się ważnym rytuałem ${ }^{10}$. Co więcej, jak pisze Martin Lindstrom:

Im bardziej szukamy stabilności, tym bardziej stajemy się zależni od dopaminy. Im więcej dopaminy potrzeba mózgowi, tym więcej rzeczy chcemy. To tak, jakbyśmy wsiedli do pędzącej windy i nie mogli już z niej wysiąść. Być może George W. Bush wiedział co nieco o mózgu, kiedy na pytanie: „Co Amerykanie mogą zrobić w niespokojnych dniach po atakach z 11 września?”, odpowiedział krótko: „Zakupy”11.

Zakupy pomagają konsumentowi odnaleźć się w świecie niestabilnym i pełnym zmian oraz spędzić ciekawie czas, zupełnie nie czując jego upływu. W galeriach handlowych nie ma ani okien, ani widocznych zegarów. Gra za to muzyka, która w zależności od pory dnia ma odpowiednio stymulować zachowania człowieka - pobudzać lub wyciszać. W galerii powinno ładnie pachnieć, budowane są również fontanny i ustawiane rośliny - tak, aby człowiek miał wrażenie obcowania z przyrodą. Wszystko jest tak zaprojektowane, by konsument mógł w poczuciu pełnego bezpieczeństwa spokojnie oddawać się zakupom i konsumpcji.

Ritzer pisze o galeriach handlowych:

dla wielu osób mają one magiczny, niekiedy wręcz religijny charakter. Aby przyciągać coraz to więcej konsumentów, muszą one oferować - albo przynajmniej sprawiać wrażenie, że oferują - coraz bardziej magiczne, fantastyczne, urzekające miejsca konsumpcji12.

Homo consumens nie myśli racjonalnie, to nie jest homo sapiens. Homo consumens szuka wrażeń, nowych doświadczeń, przyjemności, wygody, często postępuje irracjonalnie, dokonując wyborów konsumpcyjnych.

10 Por. K. Walotek-Ściańska, Homo Consumens, dz. cyt. Por. M. Lindstrom, Zakupologia: prawda i kłamstwa o tym, dlaczego kupujemy, dz. cyt. s. 104-121.

11 M. Lindstrom, Zakupologia: prawda i kłamstwa o tym, dlaczego kupujemy, dz. cyt., s. 180.

12 G. Ritzer, Magiczny świat konsumpcji, dz. cyt., s. 23. 
Konsumowanie dla niego to z jednej strony radość, a z drugiej przymus kto nie konsumuje, ten się nie liczy ${ }^{13}$.

\section{Konsumpcjonizm jako błąd mentalny}

Dla konsumenta najważniejsze są dobra materialne, a pieniądz gra główną rolę. Konsument podporządkowany regułom świata konsumpcji wybiera zawód nie zgodnie z zainteresowaniami, ale ze względu na możliwość osiągnięcia finansowego sukcesu (przykładowo ktoś studiuje medycynę, by mieć w przyszłości świetną, dobrze płatną pracę; chęć niesienia pomocy i tzw. powołanie zostają zepchnięte na drugi plan). Człowiek staje się konsumentem, podporządkowanym materialnym dobrom, gdy zaczyna wartościować zgodnie $\mathrm{z}$ wymaganiami świata konsumpcji. Ma to miejsce wtedy, gdy w miejsce wartości wyższych (duchowy i religijnych), pojawiają się dobra materialne, a główną rolę odgrywają wartości niższe. Michael Sandel mówi w tym kontekście o tzw. tryumfalizmie rynkowym - fenomenie obecnie spotykanym, który polega na tym, że prawie wszystko można kupić. Jest to możliwe dlatego, że człowiek za pieniądze, dla pieniędzy, jest w stanie sprzedać dosłownie wszystko ${ }^{14}$. W tym również tkwi problem konsumpcjonizmu.

Co zatem powinien zrobić człowiek, który z jednej strony jest i zawsze pozostanie konsumentem, a z drugiej nie chce zostać całkowicie podporządkowany zasadom rynku i świata konsumpcji, lecz wybiera personalistyczne podejście do człowieka i świata? Intersująca jest strategia oporu przed konsumpcjonizmem, która jednocześnie nie spowoduje, że człowiek zostanie wyrzucony na margines świata konsumpcji jako zbędny baumanowski „człowiek-śmieć”, „człowiek na przemiał” ${ }^{15}$. Jan Paweł II uznał, że konsumpcjonizm to błąd mentalny. Polega on na niewłaściwym

${ }_{13}$ Por. J. Baudrillard, Społeczeństwo konsumpcyjne..., dz. cyt., s. 94, 240.

14 Sandel podaje szereg przykładów, co współcześnie można kupić, a co w przeszłości nie mogło być sprzedane $\mathrm{z}$ różnych powodów, między innymi stopień zaawansowania rozwoju techniki, w tym techniki medycznej. Zob. M. Sandel, Czego nie można kupić za pieniądze: moralne granice rynku, przeł. A. Chromik, T. Sikora, Warszawa 2013, passim.

15 Z. Baumann, Życie na przemiał, Kraków 2005, s. 67. 
używaniu posiadanych dóbr i niewłaściwym do nich stosunku, czyli na uznaniu zasad świata konsumpcji za najważniejsze. Właściwe korzystanie z dóbr doczesnych papież uznaje za zasadne i mówi o tym w kontekście szeroko rozumianego rozwoju. Niebezpieczeństwo, które dostrzega, leży w przekroczeniu umiaru. W encyklice Sollicitudo rei socialis czytamy:

Rozwój nie tylko ekonomiczny mierzy się i ukierunkowuje według tej rzeczywistości i powołania człowieka wdzianego całościowo, czyli według jego „parametru” wewnętrznego. Potrzebuje on niewątpliwe dóbr stworzonych i wytworów przemysłu wzbogacanego stałym postępem naukowym i technologicznym. Wciąż nowe możliwości dysponowania dobrami materialnymi, jeśli służą zaspokajaniu potrzeb, otwierają nowe horyzonty. Niebezpieczeństwo nadużyć o charakterze konsumistycznym oraz zjawisko sztucznych potrzeb [podkreślenie - J. M. B.] nie powinny bynajmniej przeszkadzać w uznaniu i użytkowaniu nowych dóbr oraz zasobów będących do naszej dyspozycji; co więcej, powinniśmy widzieć w nich dar Boży i odpowiedź na powołanie człowieka, które w pełni urzeczywistnia się w Chrystusie ${ }^{16}$.

Święty Jan Paweł II wskazuje w przytoczonym cytacie, gdzie leży niebezpieczeństwo: w niewłaściwym używaniu dóbr oraz w uleganiu sztucznym potrzebom. Niewłaściwe używanie polega na fragmentarycznym postrzeganiu potrzeb człowieka, a przecież człowieka należy ujmować całościowo - we wszystkich sferach jego życia. Co więcej, dobra materialne użytkowane właściwie - czyli z umiarem oraz z uwzględnieniem całościowej i jednocześnie personalistycznej wizji człowieka - otwierają nowe horyzonty. Wszystko zależy od tego, jak konkretny człowiek ustosunkuje się do dóbr i w jaki sposób będzie ich używał. Samo posiadanie dóbr nie jest złe.

W przytoczonym cytacie uwagę zwraca sformułowanie „sztuczne potrzeby". Rozszyfrowanie tego sformułowania daje odpowiedź na pytanie, jak powinien postępować człowiek, który nie chce popaść w konsumpcjonizm, czyli tłumaczy, jak powinna wyglądać konsumpcja umiarkowana - taka, jaka jest właściwa dla osoby ludzkiej, obdarzonej niezbywalną

16 Jan Paweł II, Encyklika Sollicitudo rei socialis, 1987, nr 29. 
godnością. Sztuczne potrzeby to potrzeby wykreowane po to, by człowiek powiększał stale swój stan posiadania, by pożądał przede wszystkim nowych dóbr materialnych. Dzięki temu konsumpcja rośnie, możliwy jest dalszy rozwój przemysłu i firm produkcyjnych. Konkretnego człowieka sztuczne potrzeby potrafią unieszczęśliwić i uczynić niewolnikiem świata konsumpcji. Dość trudno stwierdzić, co bezwarunkowo jest sztuczną potrzebą. Czy są to dobra luksusowe, bez których można się obejść? Czy pragnienie posiadania wygodnego samochodu ekskluzywnej marki można zaliczyć do sztucznych potrzeb? Nie jest to tak proste, jak się wydaje. Sztuczna potrzeba, to potrzeba, która raczej nie ma na celu dobra człowieka jako człowieka, ale tego, kto ją wykreował i kto na niej zarobi. W Sollicitudo rei socialis możemy dalej przeczytać:

Jawi się zatem następujący obraz: są tacy, nieliczni, którzy posiadają wiele i nie potrafią prawdziwie „być”, bowiem na skutek odwrócenia hierarchii wartości przeszkodą staje się dla nich kult „posiadania”; są także i tacy, liczni, którzy mają mało lub nic i którzy nie są w stanie realizować swego zasadniczego ludzkiego powołania z powodu braku niezbędnych dóbr ${ }^{17}$.

Według Jana Pawła II zło i błąd konsumpcjonizmu nie polegają na "mieć" jako takim, ale na takim posiadaniu, które nie uwzględnia jakości i uporządkowanej hierarchii posiadanych dóbr, w której dobra materialne służą wyższym wartościom. Chodzi o jakość i hierarchię, która pozwala człowiekowi panować nad dobrami i nimi zarządzać w celu poprawy w duchu personalistycznym - swojego życia. Dzięki temu człowiek pozostaje panem nie tylko posiadanych dóbr, ale również samego siebie nie ulega presji świata konsumpcji i nie staje sługą tego, co posiada, lub tego, czego nie posiada, a posiadać powinien zgodnie z opiniami opinii publicznej świata konsumpcji. Głównym problemem wydaje się być rozpowszechniony w konsumpcjonizmie kult posiadania oraz mierzenie wartości człowieka przy pomocy kryterium, jakim są finansowe zasoby jednostki. Gdy człowiek ulega kultowi posiadania, to, co posiada, zaczyna

17 Jan Paweł II, Encyklika Sollicitudo rei socialis, nr 28. 
przejmować nad nim władzę i człowiek dobrowolnie, i często również nieświadomie, zaczyna służyć temu, co posiada lub posiadać chciałby. Następuje wówczas odwrócenie hierarchii - człowiek staje się niewolnikiem tego, co powinno mu służyć do prowadzenia dobrego życia, tego, co miało mu dać szczęście. Co gorsza, takie konsumpcyjne szczęście, które osiąga się poprzez posiadanie, może być bardzo ulotne - wraz z utratą dobra będącego jego wyznacznikiem człowiek traci również poczucie szczęścia ${ }^{18}$.

Problem posiadania i służenia temu, co się posiada, jest dość złożony. Człowiek, który spłaca kredyt zaciągnięty na mieszkanie, jest z pewnością w pewien sposób ograniczony i podporządkowany konieczności spłacania rat. Według Baudrillarda jest on „nowym niewolnikiem”, ponieważ nie może (poza spłaceniem zobowiązania) wyzwolić się z konieczności płacenia, a zatem służy temu, co posiada ${ }^{19}$. Baudrillard nie dostrzega, opisując nowego niewolnika (czyli osoby „zakredytowane”), że nie każdy kredyt czyni z człowieka sługi banku. Kredyt zaciągnięty z ważnych powodów nie oznacza bezwarunkowo, że całe życie człowieka zostało podporządkowane konieczności np. zakupu mieszkania (lud innego dobra na kredyt). Problem tkwi gdzie indziej - w stosunku człowieka do dóbr, również tych kupowanych na kredyt i w umiejętności „mierzenia siły na zamiary”, stosowania w praktyce słynnej arystotelesowskiej cnoty umiarkowania.

Jan Paweł II również w słynnej encyklice Redemptor hominis pisze o cywilizacji konsumpcyjnej:

Sytuacja człowieka w naszej epoce nie jest oczywiście jednolita, jest wielorako zróżnicowana. Różnice te mają swoje przyczyny historyczne. Mają jednak równocześnie swój potężny wydźwięk etyczny. Jest przecież dobrze znany fakt cywilizacji konsumpcyjnej, która ma swoje źródło w jakimś nadmiarze dóbr potrzebnych dla człowieka, dla całych społeczeństw - a chodzi tu właśnie o społeczeństwo bogate

18 To tzw. pułapka szczęścia świata konsumpcji. Zob. B. Żmuda, Pułapka szczęścia współczesnego człowieka, „Logos i Ethos” $2016 \mathrm{nr} 40$ (numer specjalny), s. 41-50.

19 Zob. J. Baudrillard, Społeczeństwo konsumpcyjne..., dz. cyt., s. 94. 
i wysoko rozwinięte - podczas gdy z drugiej strony inne społeczeństwa, przynajmniej szerokie ich kręgi, głodują, a wielu codziennie umiera z głodu, z niedożywienia. W parze z tym idzie jakieś nadużycie wolności jednych, co łączy się właśnie z niekontrolowaną etycznie postawą konsumpcyjną, przy równoczesnym ograniczaniu wolności drugich, tych, którzy odczuwają dotkliwe braki, którzy zostają zepchnięci w warunki nędzy i upośledzenia ${ }^{20}$.

W przytoczonym cytacie pada kolejne interesujące sformułowanie „cywilizacja konsumpcyjna”. To bardzo poważny zarzut, to coś więcej niż społeczeństwo konsumpcyjne czy świat konsumpcji. Cała cywilizacja może być przesiąknięta konsumpcjonizmem. Mamy zatem do czynienia z sytuacją, w której dóbr jest w nadmiarze w społeczeństwie bogatym, podczas gdy poza nim ludzie umierają z głodu. Dla Jana Pawła II to przykład nadużycia wolności przez tych, którzy są bogaci. Świat konsumpcji, który w większości przypadków dotyczy państw demokratycznych, każdemu obywatelowi przyznaje wolność formalną - to szereg prawnych zapisów gwarantowanych przez odpowiednie instytucje. Dla świata konsumpcji jest to podstawa do swobodnego rozwoju, ale dla jednostek zaczyna się liczyć w tym świecie inny rodzaj wolności, który jest mierzony ilością posiadanych środków finansowych. Ten konsument jest faktycznie wolny, który może sobie pozwolić na życie w dostatku, biedny jest ograniczony w korzystaniu ze swojej wolności, nadal pozostaje formalnie wolny, ale faktycznie pozwala się zniewolić, w imię zapewnienia sobie lepszego standardu życia ${ }^{21}$.

Konsumpcjonistyczny nadmiar oferowanych dóbr, z jakim na co dzień się spotykamy, stanowi dla człowieka wyzwanie, które uwidacznia się w konieczności codziennego stawiania sobie prostego pytania: ile i jakich dóbr rzeczywiście potrzebuję? W jaki sposób moja konsumpcja

20 Jan Paweł II, Encyklika Redemptor hominis, 1979, nr 16.

${ }^{21}$ Na przykład nie jest w stanie wziąć udział w wyborach, ponieważ nie ma pieniędzy na autobus, by dojechać do lokalu wyborczego. O rozróżnieniu równości faktycznej i formalnej oraz wolności faktycznej i wolności formalnej, a także konsekwencji braku zarówno równości, jak i wolności faktycznej zob. A. Swift, Wprowadzenie do filozofii politycznej, przeł. A. Krzynówek, Kraków 2010, s. 59n; por. J. Mysona Byrska, Zbywatele, prekariusze i praca w świecie konsumpcji, dz. cyt., s. 214. 
wpływa na rzeczywistość otaczającego mnie świata? Może trzeba się podzielić albo zaprotestować przeciwko proponowanym podziałom różnorodnych dóbr? Nie oznacza to rezygnacji z życia w dobrobycie, jest to wymóg dostrzegania kosztów owego dobrobytu i świadomego korzystania.

Konsumpcjonizm to wyzwanie dla człowieka, ponieważ bardzo łatwo być konsumentem. Wystarczy ulec naturalnej skłonności do skupiania uwagi na sobie i tylko sobie i spełniać własne pragnienia bez liczenia się $\mathrm{z}$ innymi. Konsument opanowany przez dobra materialne i świat zabawy nie ma czasu na refleksję, nie potrafi się oderwać od konsumowania i bawienia się. Człowiek, który jest nie tylko konsumentem, potrafi ograniczyć czas przeznaczony na konsumpcję, dostrzega świat dookoła siebie, potrafi się zaangażować, zatrzymać i zastanowić. Może działać jako obywatel na rzecz innych i de facto samego siebie, dbając o swoje bezpośrednie otoczenie. Dzięki temu ma szansę władać, zarządzać posiadanymi dobrami. Konsument tego nie potrafi - jest sterowany przez reguły świata konsumpcji, przez strategie marketingowe mówiące mu, co i gdzie ma jeść, jak się ubierać, bawić, spędzać wolny czas oraz kiedy jest szczęśliwy.

Konsumentem człowiek staje się stopniowo, jest to proces, który często przebiega niezauważalnie. W pewnej chwili okazuje się, że dobra materialne przejęły władzę nad człowiekiem i że człowiek im służy. Problem konsumenta polega również na tym, że nie dostrzega owej zmiany, stara się być szczęśliwy na miarę świata konsumpcji, kupując, aby w ten sposób zapełnić egzystencjalną pustkę, która pojawia się, gdy nie bierze udziału w konsumpcyjnych rozrywkach. Można uniknąć popadnięcia w niewolę konsumpcjonizmu dzięki pielęgnowaniu cnoty umiaru, co może wyglądać na co dzień bardzo prosto. Przy każdym zakupie - zwłaszcza typu chwilowej zachcianki, ponad to co zaplanowane - należy zadać sobie pytanie - czy rzeczywiście jest to potrzebne? Co ciekawsze, nawet jeśli odpowiedź brzmi: nie jest potrzebne, a mimo to konsument kupuje dany przedmiot lub usługę, to sam fakt zadania pytania pozwala uchronić się przed stopniowym stawaniem się bezrefleksyjnym konsumentem. 


\section{Bibliografia}

Bakan J., Dzieciństwo w stanie oblężenia. Łatwy cel wielkiego biznesu, Warszawa 2013. Baudrillard J., Społeczeństwo konsumpcyjne. Jego mity i struktury, Warszawa 2006.

Bauman Z., Straty uboczne: nierówności społeczne w epoce globalizacji, przeł. J. Hunia, Kraków 2012.

Baumann Z., Życie na przemiał, Kraków 2005.

Jan Paweł II, Encyklika Redemptor hominis, 1979.

Jan Paweł II, Encyklika Sollicitudo rei socialis, 1987.

Kant I., Uzasadnienie metafizyki moralności, przeł. M. Wartenberg, Warszawa 1984.

Lindstrom M., Zakupologia: prawda i kłamstwa o tym, dlaczego kupujemy, przeł. M. Zielińska, Kraków 2009.

Mysona Byrska J., The Promotion of the Infantilism Ethos in Consumer Society, „Ethics \& Bioethics (in Central Europe)" 5 (2015) issue 1-2, s. 59-66.

Mysona Byrska J., Zbywatele, prekariusze i praca w świecie konsumpcji, „Filo-Sofija” 15 (2015) nr 29 (2/II): Z problemów współczesnej filozofii, s. 205-217.

Ritzer G., Magiczny świat konsumpcji, przeł. H. Jankowska, Warszawa 2009.

Sandel M., Czego nie można kupić za pieniądze: moralne granice rynku, przeł. A. Chromik, T. Sikora, Warszawa 2013.

Swift A., Wprowadzenie do filozofii politycznej, przeł. A. Krzynówek, Kraków 2010.

Walotek-Ściańska K., Homo Consumens, http://www.sbc.org.pl/Content/134276/Walotek\%C5\%9Acia\%C5\%84ska.pdf (25.04.2017).

Żmuda B., Pułapka szczęścia współczesnego człowieka, „Logos i Ethos” 2016 nr 40 (numer specjalny), s. 41-50.

\section{Abstrakt}

\section{Konsumpcjonizm jako błąd mentalny}

Konsumpcjonizm to niewłaściwy stosunek do przedmiotów i niewłaściwy sposób ich używania. Dla Jana Pawła II to przykład mentalnego błędu. Człowiek jest i zawsze będzie konsumentem - konsumpcja jest wpisana w istotę bycia człowiekiem. Problem polega na właściwym stosunku do rzeczy i nadawaniu właściwej miary znaczeniu przedmiotów, które człowieka otaczają. Człowiek popada w konsumpcjonizm, gdy podporządkowuje 
swoje życie dobrom materialnym tak, że one zaczynają nadawać sens jego życiu. Odwraca się wówczas porządek uznawany przez Jana Pawła II za właściwy - w miejsce człowieka panującego nad przedmiotami to one zaczynają nim władać i kierować jego życiem. Przeciwdziałać temu można przez praktykowanie cnoty umiaru i roztropności.

\section{Słowa klucze}

konsumpcjonizm, świat konsumpcji, umiar

\section{Abstract \\ Consumerism as a Mental Error}

Consumerism is an irrelevant relation towards objects and an inappropriate way of using them. For John Paul II it is an example of a mental error. A human being is and always will be a consumer - consumption is inscribed in the substance of being a men. The main concern is a relevant relation toward objects and giving an appropriate measure to the meaning of surrounding objects. One falls into consumerism when he submits his life to material goods and they begin to give meaning to his life. The order considered by John Paul II to be appropriate is reversed - instead of a men controlling objects, they are starting to prevail over him and give orientation to his life. Counteract can only practicing a virtue of moderation and wisdom.

\section{Keywords}

consumerism, world of consumption, moderation 